\title{
RNA-binding proteins in ovarian cancer: a novel avenue of their roles in diagnosis and treatment
}

Jiangchun $\mathrm{Wu}^{1,2+}$, Yong $\mathrm{Wu}^{1,2+}$, Qinhao Guo ${ }^{1,2}$, Simin Wang ${ }^{1,2}$ and Xiaohua Wu ${ }^{1,2^{*}}$

\begin{abstract}
Ovarian cancer (OC), an important cause of cancer-related death in women worldwide, is one of the most malignant cancers and is characterized by a poor prognosis. RNA-binding proteins (RBPs), a class of endogenous proteins that can bind to mRNAs and modify (or even determine) the amount of protein they can generate, have attracted great attention in the context of various diseases, especially cancers. Compelling studies have suggested that RBPs are aberrantly expressed in different cancer tissues and cell types, including OC tissues and cells. More specifically, RBPs can regulate proliferation, apoptosis, invasion, metastasis, tumorigenesis and chemosensitivity and serve as potential therapeutic targets in OC. Herein, we summarize what is currently known about the biogenesis, molecular functions and potential roles of human RBPs in OC and their prospects for application in the clinical treatment of OC.
\end{abstract}

Keywords: Ovarian cancer, RNA-binding proteins, Therapeutic targets

\section{Introduction}

Ovarian cancer (OC) has been reported to be the fifth leading cause of death among females, and an estimated 21,410 new cancer cases and 13,770 cancer-related deaths occurred in the United States in 2020 [1]. Most patients are diagnosed at an advanced stage of disease due to the deep anatomical position in the pelvic cavity and the lack of specific diagnostic symptoms or biomarkers [2]. Standard treatment, including surgery and chemotherapy, is usually effective at inducing remission, but in $70-80 \%$ of patients, the cancer recurs within 2 years [3]. OC is characterized by advanced stage diagnosis, rapid progression, high metastasis and recurrence rates, and rapid drug resistance development [4]. Despite numerous efforts to improve the efficacy of surgery, chemoradiotherapy, and targeted treatments, such as antiangiogenic

\footnotetext{
*Correspondence: wu.xh@fudan.edu.cn; docwuxh@hotmail.com

${ }^{\dagger}$ Jiangchun Wu and Yong Wu contributed equally to this work

1 Department of Oncology, Shanghai Medical College, Fudan University, Shanghai 200032, China

Full list of author information is available at the end of the article
}

drugs and poly (ADP-ribose) polymerase inhibitors, few reliable biomarkers or notably better therapeutic strategies for treating $\mathrm{OC}$ in daily clinical practice have been discovered in recent years [5].

RNA-binding proteins (RBPs) are proteins that play critical roles in the regulation of many RNA transcripts at multiple posttranscriptional levels [6]. Several studies have demonstrated that RBPs are abnormally expressed in cancer tissues relative to adjacent normal tissues, and this expression is related to patient prognosis [7-9]. Studies by our research group revealed a significant role of CUGBP- and ETR-3-like family 2 (CELF2) and Lin28 homologue B (LIN28B) in OC progression, and our interest in RBPs has grown [10]. Therefore, summarizing the functions and mechanisms of RBPs may broaden the field of $\mathrm{OC}$ research.

\section{Biogenesis and domain features of RBPs Biogenesis}

RBPs are proteins that bind at specific target sites and impact the expression of coordinated sets of mRNAs original author(s) and the source, provide a link to the Creative Commons licence, and indicate if changes were made. The images or other third party material in this article are included in the article's Creative Commons licence, unless indicated otherwise in a credit line to the material. If material is not included in the article's Creative Commons licence and your intended use is not permitted by statutory regulation or exceeds the permitted use, you will need to obtain permission directly from the copyright holder. To view a copy of this licence, visit http://creativecommons.org/licenses/by/4.0/. The Creative Commons Public Domain Dedication waiver (http://creativecommons.org/publicdomain/zero/1.0/) applies to the data made available in this article, unless otherwise stated in a credit line to the data. 
[11]. The abnormal expression of RBPs has been widely reported in multiple types of cancer cells and is regulated by numerous mechanisms, including genomic control, transcriptional regulation, posttranscriptional modification (PTM), and posttranslational modification [12] (Fig. 1).

Genomic mutations, a prevalent feature of cancer cells, appear to have a minor contribution to abnormal RBP expression. Mutations in genes encoding RBPs are particularly rare compared to those in other genes [13, 14]. Somatic mutations, especially in spliceosome genes, are associated with haematopoietic disorders that result in acute myeloid leukaemia $[15,16]$. Germline mutations in the DICER1 gene, which encodes a cytoplasmic endoribonuclease that processes precursor messenger RNAs (pre-mRNAs) into mature mRNAs, are reported for less than $1 \%$ of RBPs by the Online Mendelian Inheritance in Man database [16-18]. In addition, chromosomal translocations involving RBPs are relatively rare in cancer. In contrast, copy number variations are more common and are related to the deregulation of RBP expression [19].

RBP expression deregulation is also driven by transcriptional alterations [20, 21]. For example, RBP38 expression can be induced by the tumour suppressor P53, which in turn mediates the stabilization of P53 downstream target mRNAs that promote cell cycle arrest in the G1 phase $[22,23]$. Posttranscriptional alteration is another mechanism involved in RBP expression deregulation [24]. The expression of the RBP Musashi 1 (MSI1) can be repressed by a class of tumour suppressor miRNAs, including miR34a, miR-138, and miR-137, inhibiting the proliferation of glioblastoma and medulloblastoma cells [25, 26].

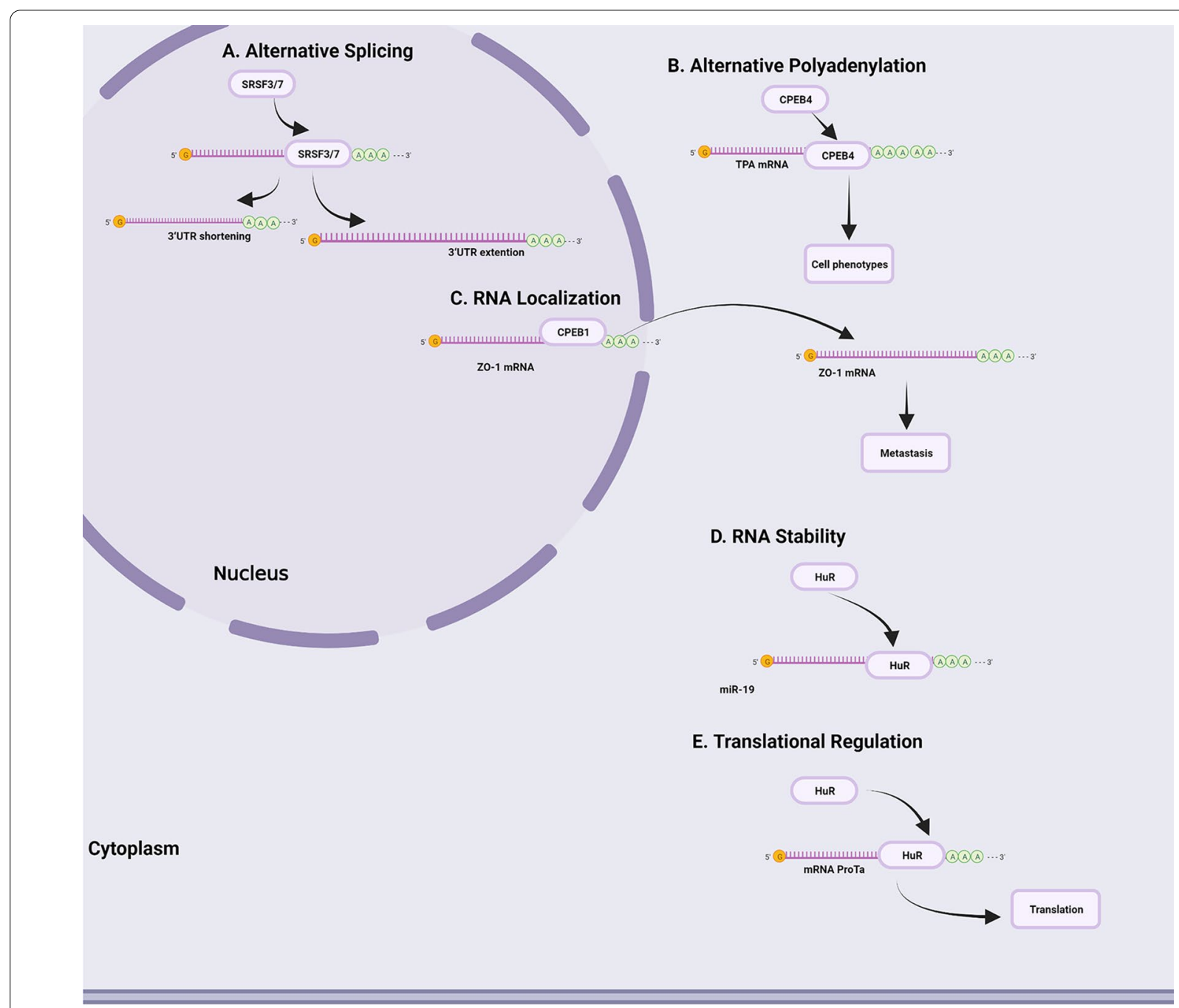

Fig. 1 Various mechanisms regulate changes in RBP expression in cancer cells. A Genomic control. B Transcriptional regulation. C Posttranscriptional regulation. D Posttranslational modifications 
Recent studies have emphasized the role of translational modification in RBP expression deregulation. RBPs are hotspots for posttranscriptional modifications (PTMs), including acetylation, phosphorylation, methylation, and ubiquitination $[27,28]$. For example, the acetylation of the RBP SAM68 can enhance its binding to mRNA and play a critical role in cell cycle control [29].

Overall, these studies provide an overview of the changes in RBPs involved in various mechanisms that may be therapeutic targets in the future.

\section{Domain features of RBPs}

Through next-generation sequencing (NGS) of diverse tumour cell types, a catalogue of 1542 experimentally validated human RBPs representing approximately $7.5 \%$ of all protein-coding genes in the genome was generated [30, 31]. Since RBPs play multiple biological roles, their structures comprise multiple small domains, including RNA recognition domains and RNA-binding domains interspersed between catalytic domains that enable them to recognize a wide range of downstream targets and regulate their catalytic activities [32]. These catalytic domains include three parts: deaminases, RNAse III domains and helicases. Multiple RNA-binding domains (RBDs) can specifically recognize and bind to RNA sequences [33]. Among the RBPs represented, a quarter contain conventional RBDs, and the rest contain nonconventional RBDs. Conventional RBDs may comprise RNA recognition motifs (RRMs), zinc fingers, S1 domains, PIWI domains, double-stranded RNA-binding domains (dsRBDs), K-homology (KH) domains, PIWI, AGO, and Zwill (PAZ) domains, while nonconventional RBPs have internally disordered regions and adjust their spatial structure to bind to RNAs and subsequently mediate cell regulation, signal transduction and metabolism [34].

\section{Functions of RBPs in cancers}

Because RBPs regulate various downstream targets in omnidirectional and multifunctional manners, even small alterations in their expression or activity can cause significant changes in regulatory networks. RBPs can interact with proteins or multiple RNAs, including mRNAs and ncRNAs, to form RNP complexes [35] and subsequently regulate the functions of RNA transcripts via multiple posttranscriptional mechanisms, including RNA splicing, polyadenylation, effects on localization and stability, and translational modification [35, 36] (Fig. 2).

Alternative splicing, a fundamental posttranscriptional regulation mechanism, contributes to the complexity and diversity of the proteome, resulting in changes in cancer cell phenotype [37,38]. The regulation of alterative splicing relies on RBPs, which act as splicing factors that precisely bind to RNA motifs
A. Genomic control

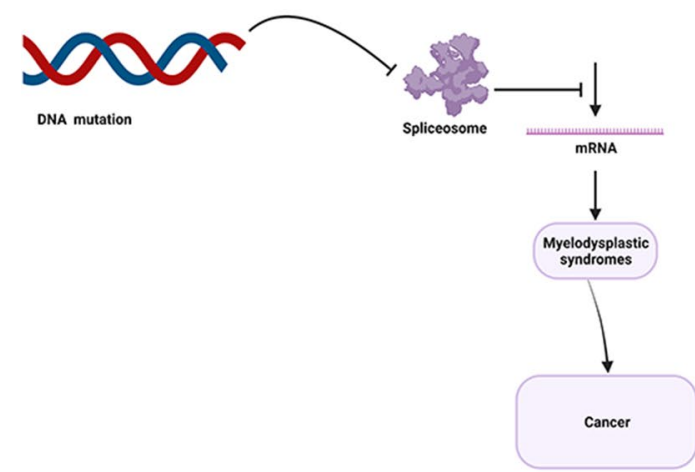

C. Post-transcriptional regulation
B.Transcriptional regulation

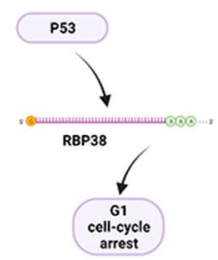

D. Post-translational modifications
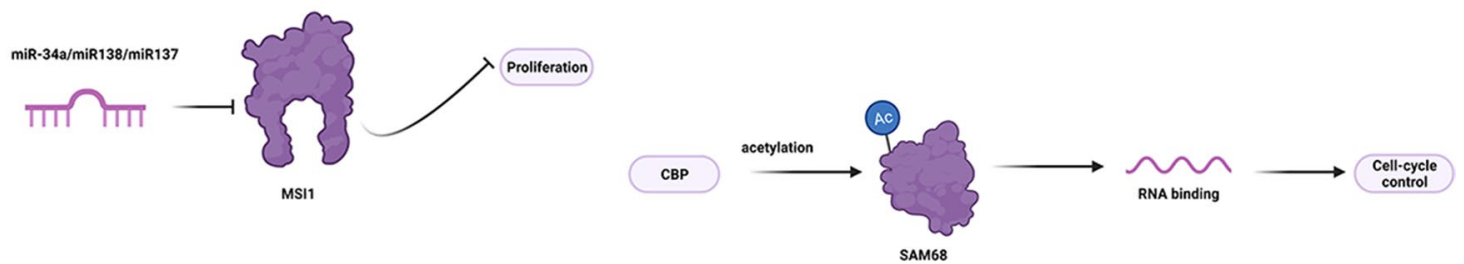

Fig. 2 RBPs regulate the functions of transcripts at multiple post-transcriptional levels. A Alternative Splicing. B Alternative Polyadenylation. C RNA Localization. D RNA Stability. E Alternative Splicing 
located in exons or their adjacent introns [38, 39]. The serine/arginine-rich (SR) protein and hnRNP families are essential RBPs that play evolutionarily conserved roles as regulators of alterative pre-mRNA splicing [40]. SRSF3 and SRSF7 have been shown to bind different sites in terminal exons and recruit NXF1 to regulate the length of the 3 ' untranslated region (UTR) [41].

Alterative polyadenylation is another process that is essential for generating mature RNA transcripts. It occurs in 3' UTRs, resulting in different lengths by cleavage and polyadenylation (CPA). The function of the 3'-UTR is essential for mRNA maturation, stability, localization, and translation. RBPs can either recruit or compete with polyadenylation machinery proteins, which regulate the cleavage and polyadenylation (CPA) of target mRNAs. In pancreatic cancer, CPEB4 regulates tail elongation with TPA mRNA, resulting in alteration of cancer cell proliferation, migration, invasion and angiogenesis [42].

RBPs also play a key role in subcellular localization by binding to the 3' UTR sequence of mRNA or other ncRNAs, nucleating the assembly of multisubunit complexes that link transcripts to cytoskeletal motors that send ribonucleoproteins (RNPs) to specific subcellular locations [43]. CPEB1 encodes an essential tight junction component that regulates the localization of ZO-1 mRNA. Its depletion may impair cell polarity, resulting in alteration of metastatic potential and EMT-related genes in breast cancer [44, 45].

RBPs also play a key role in the stabilization or destabilization of specific target mRNAs or ncRNAs. The stability of RNAs is determined by their 3' poly(A) tail and 5'-terminal 7-methylguanosine (m7G). HuR (a member of the $\mathrm{Hu}$ family of RBPs)-mediated mRNA stabilization relies on the subcellular localization of $\mathrm{HuR}$, which is translocated into the cytoplasm and is associated with cell cycle regulators and inflammation. For example, HuR can stabilize mRNAs that encode cyclins (A, B1, D1 and E), HIF-1a, and VEGF, thus increasing the expression of these proteins. In contrast, the mRNA levels of c-Myc and WNT-5A can be destabilized by HuR in cancer cells [35, 46-48].

RBPs are involved in multiple steps of translation, such as initiation, elongation, and termination, forming RNP complexes. A large number of related RBPs bind to the 5' or 3' UTR, resulting in different translation efficiencies [49]. HuR increases the abundance and translation of ProTa mRNA by targeting its 3' UTR, which has been correlated with cancer progression [50].

\section{Profiles of RBP expression in OC}

Abnormal RBP expression can lead to genome-wide changes in the transcriptome and proteome levels and subsequently affect cell proliferation, apoptosis, angiogenesis, senescence, epithelial-mesenchymal transition (EMT), invasion, and metastasis [6]. Therefore, it is not surprising that altered expression of RBPs is common during the development and progression of cancers. Next, the alteration of RBP expression in OC is summarized (Table 1 ), and related phenotype changes are also presented (Fig. 3).

\section{RBPs act as oncogenes or tumour suppressors in modulating $O C$ phenotypes \\ Proliferation}

Insulin-like growth factor 2 mRNA-binding protein 1 (IGF2BP1/IMP1), a member of the IMP family, binds to the 5' UTR of IGF2 mRNA [51]. IGF2BP1 has the most conserved "oncogenic" role in the IGF2BP family and is associated with poor prognosis [52]. Serum response factor (SRF)-encoding mRNA acts as a downstream target of IGF2BP1, which destabilizes cell identity [53]. IMP1 is overexpressed in high serous ovarian carcinoma (HGSOC), acts as a novel m6A reader by stabilizing c-MYC mRNA, and then promotes HGSOC progression [54].

YT521-B homology (YTH) domain-containing proteins, including YTHDF1-3, YTHDF1 and YTHDF2, have been recognized as "readers" that identify m6A modifications [55]. YTHDF1 is highly expressed in HGSOC and is related to an adverse prognosis in patients. It can act as a m6A reader by specifically binding to the m6A modification of the translation initiation factor EIF3C, augmenting EIF3C translation, and promoting $\mathrm{OC}$ progression [56]. Tripartite motif protein 29 (TRIM29) is aberrantly expressed in some cancers and can act as an oncogene or tumour suppressor [57]. Our research group also revealed that F-box and WD repeat domain-containing 7 (FBW7) expression is regulated in HGSOC, where it interacts and antagonizes YTHDF2 to alter the expression levels of m6A-modified Bcl-2-modifying factor (BMF) mRNA, thereby affecting cell proliferation [58].

ELAV-like protein $1(\mathrm{HuR})$ is a member of the embryonic lethal abnormal visual system (ELAV) family. The transcriptional repressor ZEB2 not only activates EMT but also promotes the initiation and progression of cancers [59]. HuR regulates the stability and translation of ZEB2 to affect proliferation [60]. Translocase of inner mitochondrial membrane 44 (TIMM44), a peripheral membrane protein, is associated with the transport of proteins from the mitochondrial inner membrane to the mitochondrial matrix [61]. HuR modulates the 
Table 1 Experimental evidence of altered RBPs in OC

\begin{tabular}{|c|c|c|c|c|c|}
\hline \multicolumn{6}{|l|}{ Oncogenes } \\
\hline RBP & & Mechanism & Putative targets & Cellular phenotype & References \\
\hline \multirow[t]{3}{*}{$\begin{array}{l}\text { Insulin-like growth factor } 2 \\
\text { mRNA-Binding Protein }\end{array}$} & IGF2BP1/IMP1 & $\begin{array}{l}\text { mRNA stability, Inhibiting } \\
\text { decay }\end{array}$ & C-MYC, MDR1, SRF & $\begin{array}{l}\text { Platinum, } \\
\text { Chemoresistance, } \\
\text { Growth, } \\
\text { invasion }\end{array}$ & [101] \\
\hline & IGF2BP2/IMP2 & & & Proliferation & {$[90,125]$} \\
\hline & IGF2BP3/IMP3 & $\begin{array}{l}\text { mRNA stability, mRNA } \\
\text { translation }\end{array}$ & HCTR1 & $\begin{array}{l}\text { Platinum, } \\
\text { Chemoresistance, } \\
\text { Proliferation, } \\
\text { Migration, } \\
\text { Invasion }\end{array}$ & {$[70]$} \\
\hline La-Related Protein 1 & LARP1 & $\begin{array}{l}\text { mRNA stability, mRNA de- } \\
\text { stability }\end{array}$ & $\mathrm{BIK}, \mathrm{BCL} 2$ & Proliferation & {$[67]$} \\
\hline \multirow[t]{2}{*}{$\operatorname{Lin} 28$} & $\operatorname{Lin} 28 \mathrm{~A}$ & $\begin{array}{l}\text { Alternative splicing, mRNA } \\
\text { translation }\end{array}$ & ROCK2 & $\begin{array}{l}\text { Invasion, } \\
\text { Metastasis, } \\
\text { Proliferation, } \\
\text { Migration, } \\
\text { Invasion }\end{array}$ & {$[84]$} \\
\hline & LIN28B & mRNA translation & AKT2, NEAT1 & $\begin{array}{l}\text { Platinum Chemoresistance, } \\
\text { Proliferation, } \\
\text { Migration, } \\
\text { Invasion }\end{array}$ & {$[70]$} \\
\hline $\begin{array}{l}\text { Heterogeneous nuclear rib- } \\
\text { onucleoproteins (hnRNPs) }\end{array}$ & hnRNPA2B1 & mRNA stability & $\operatorname{Lin} 28 B$ & $\begin{array}{l}\text { Proliferation, } \\
\text { Invasion, } \\
\text { Migration, } \\
\text { Apoptosis }\end{array}$ & {$[69]$} \\
\hline $\begin{array}{l}\text { Hu family of RBPs (ELAV-like } \\
\text { protein 1) }\end{array}$ & HuR & $\begin{array}{l}\text { mRNA stability, mRNA } \\
\text { translation }\end{array}$ & $\begin{array}{l}\text { TUBB3, InCRNA NEAT1, } \\
\text { InCRNA MALAT1, InCRNA } \\
\text { HOTAIR, ZEB2, TP53, E2F2 }\end{array}$ & $\begin{array}{l}\text { Proliferation, } \\
\text { Invasion, } \\
\text { Migration, } \\
\text { Paclitaxel resistance }\end{array}$ & {$[60,64,91-93]$} \\
\hline Y-box binding protein 1 & YB1 & $\begin{array}{l}\text { mRNA stability, Translation } \\
\text { modification }\end{array}$ & & Chemotherapy resistance & {$[106]$} \\
\hline \multirow[t]{2}{*}{$\begin{array}{l}\text { YT521-B homology (YTH) } \\
\text { domain-containing proteins }\end{array}$} & YTHDF1 & mRNA translation & $\begin{array}{l}\text { EIF3C, } \\
\text { TRIM29 }\end{array}$ & Chemotherapy resistance & {$[56,126]$} \\
\hline & YTHDF2 & mRNA translation & BMF & $\begin{array}{l}\text { Proliferation, } \\
\text { Migration, } \\
\text { Invasion, } \\
\text { Apoptosis }\end{array}$ & {$[58]$} \\
\hline $\begin{array}{l}\text { Polypyrimidine-tract bind- } \\
\text { ing protein-associated } \\
\text { splicing factor }\end{array}$ & SFPQ & Alternative splicing & Caspase-9 & Apoptosis & {$[70]$} \\
\hline Forkhead box protein C2 & $\mathrm{FOXC2}$ & & GClnc1 & EMT & {$[95]$} \\
\hline epithelial cell RBP & ESRP1 & Alternative splicing & Circ-NOLC1 & Prognosis & {$[72]$} \\
\hline \multicolumn{6}{|l|}{ Tumour suppressors } \\
\hline RNA-binding motif protein 3 & RBM3 & Translation & $B C L-2, B A X$ & Platinum sensitivity & {$[3,77]$} \\
\hline $\begin{array}{l}\text { CUGBP and ETR-3-like } \\
\text { family } 2\end{array}$ & CELF2 & mRNA stability & FAM198B & $\begin{array}{l}\text { Proliferation, } \\
\text { Migration, } \\
\text { Invasion }\end{array}$ & {$[10]$} \\
\hline Poly C Binding Protein 1 & PCBP1 & translational & p27 & Inhibiting OC progress & {$[78]$} \\
\hline $\begin{array}{l}\text { heterogeneous nuclear } \\
\text { family (hnRNPI) }\end{array}$ & PTB & Alternative splicing & & & {$[88]$} \\
\hline $\begin{array}{l}\text { Coiled-coil domain contain- } \\
\text { ing protein- } 124\end{array}$ & Ccdc124 & & & Prognosis & {$[79]$} \\
\hline Y-box binding protein 1 & YBX1/YB1 & & & $\begin{array}{l}\text { Prognosis, resistance to } \\
\text { cisplatin }\end{array}$ & {$[106]$} \\
\hline $\begin{array}{l}\text { DEAD-Box Helicase } \\
3 X \text {-Linked }\end{array}$ & DDX3X & Translation & $\mathrm{PHGDH}$ & & {$[80]$} \\
\hline
\end{tabular}


Table 1 (continued)

\begin{tabular}{|c|c|c|c|c|c|}
\hline \multicolumn{6}{|l|}{ Oncogenes } \\
\hline RBP & & Mechanism & Putative targets & Cellular phenotype & References \\
\hline $\begin{array}{l}\text { PAl-1 mRNA Binding Protein } \\
1\end{array}$ & PAI-RBP1 & & PAI-1 & Progression & {$[83]$} \\
\hline $\begin{array}{l}\text { Sorbin and SH3 domain- } \\
\text { containing } 2\end{array}$ & SORBS2 & & WFDC1, IL-17D & Cell migration, Metastatic & {$[99]$} \\
\hline RNA-binding motif protein 3 & RBM3 & $\begin{array}{l}\text { DNA damage, Repair } \\
\text { adverse cytotoxic effects } \\
\text { after chemotherapy }\end{array}$ & $\mathrm{BCL}-2, \mathrm{BAX}, \mathrm{DNA}$ integrity & $\begin{array}{l}\text { Prognosis, Platinum sensitiv- } \\
\text { ity }\end{array}$ & {$[3,77]$} \\
\hline Quaking isoforms 5 & QKI5 & stability & TAZ & inhibit metastasis & {$[100]$} \\
\hline
\end{tabular}

expression of TIMM44 by stabilizing its mRNA levels, and its expression is correlated with OC cell progression [62]. E2F2 is a transcription activator that plays an important role in cancer progression [63]. CircE2F2 can bind to HuR to stabilize E2F2 mRNA and consequently promote $\mathrm{OC}$ cell proliferation, glucose metabolism and metastasis [64].

La-related protein 1 (LARP1) is a highly evolutionarily conserved RBP of the LARP family. It can regulate the stability and translation of mRNAs associated with ribosome biogenesis and cell proliferation [65]. LARP1 interacts with the 3' UTRs of BIK (encodes a pro-apoptotic protein) and BCL2 (B-cell lymphoma 2, encodes an anti-apoptotic protein), stabilizes BCL2, and destabilizes BIK with a net effect of promoting OC proliferation $[66,67]$.

Heterogeneous nuclear ribonucleoproteins (hnRNPs) have been considered crucial tumour oncogenes related to proliferation and apoptosis. hnRNPA2B1 has two isoforms, hnRNPA2 and hnRNPB1, that regulate different gene expression patterns and phenotypes in various cancers [68]. HnRNPA2B1 binds to and stabilizes the transcript level of Lin28B, thereby promoting serous ovarian cancer (SOC) cells progression [69]. In addition, IGF2BP3 targets downstream human copper transporter 1 (hCTR1), induces chemoresistance and is correlated with a poor prognosis in SOC patients [70].

ESRP1, an epithelial cell RBP, participates in the EMT process by regulating alternative splicing and is associated with a poor prognosis [71]. Circ-NOLC1 promotes EOC progression by binding to ESRP1 and modulates cell-dependent kinase 1 (CDK1) and Ras homologous family member A (RhoA) expression [72].

MicroRNAs are small endogenous noncoding RNAs that regulate gene expression by promoting the degradation and/or repressing the translation of their target mRNAs. The first step in miRNA maturation is executed by the Drosha microprocessor, in which the RNase III enzyme Drosha (Drosha) and DiGeorge syndrome critical region gene 8 (DGCR8) are the core components $[73,74]$. DGCR8 can recognize primary miRNAs and promote their methylation with the help of the methylase METTL3 [75]. Dorsha can also be recruited to double-stranded RNA and thereby produce precursor miRNAs [76]. The RBP DDX1 belongs to the DEAD-box helicase family, which can promote primiRNA maturation and repress OC progression [75].

Expression of RNA-binding motif protein 3 (RBM3), a member of the glycine-rich RNA binding protein (GRP) family, was highly upregulated in OC tissues and A2780 OC cell lines. RBM3 positively regulates the DNA damage response in $\mathrm{OC}$ cells and can act as a novel oncogenic prognostic biomarker for OC patients [77].

Poly C-binding protein 1 (PCBP1) can bind to the 3' UTR of the cell cycle inhibitor p27 via its KH1 domain, thereby stabilizing p27 and inhibiting $\mathrm{OC}$ progression [78].

Coiled-Coil Domain Containing protein-124 (Ccdc124) is an mRNA-binding factor related to cell division and ribosome biology. Upregulated Ccdc124 expression was associated with a prolonged prognosis in OC patients [79].

The RBP of DEAD-Box Helicase 3X-Linked (DDX3X) can be stabilized by RNA Component of Mitochondrial RNA Processing Endoribonuclease (lncRNA RMRP) and promotes Phosphoglycerate dehydrogenase (PHGDH) mRNA translation, thus conferring resistance of OC cells and inhibiting OC progression [80]. Overexpression of DDX3X can reverse miR-196a-mediated OC progression by activating PTEN expression and suppressing AKT activity [81].

The plasminogen activator (PA) system plays an important role in the invasion and metastasis of $\mathrm{OC}$, and PA inhibitor type 1 (PAI-1) is the main subtype [82]. PAI-RBP1 (PAI-1 mRNA-Binding Protein 1) contributes to $\mathrm{OC}$ progression by binding and stabilizing PAI-1 mRNA [83]. 


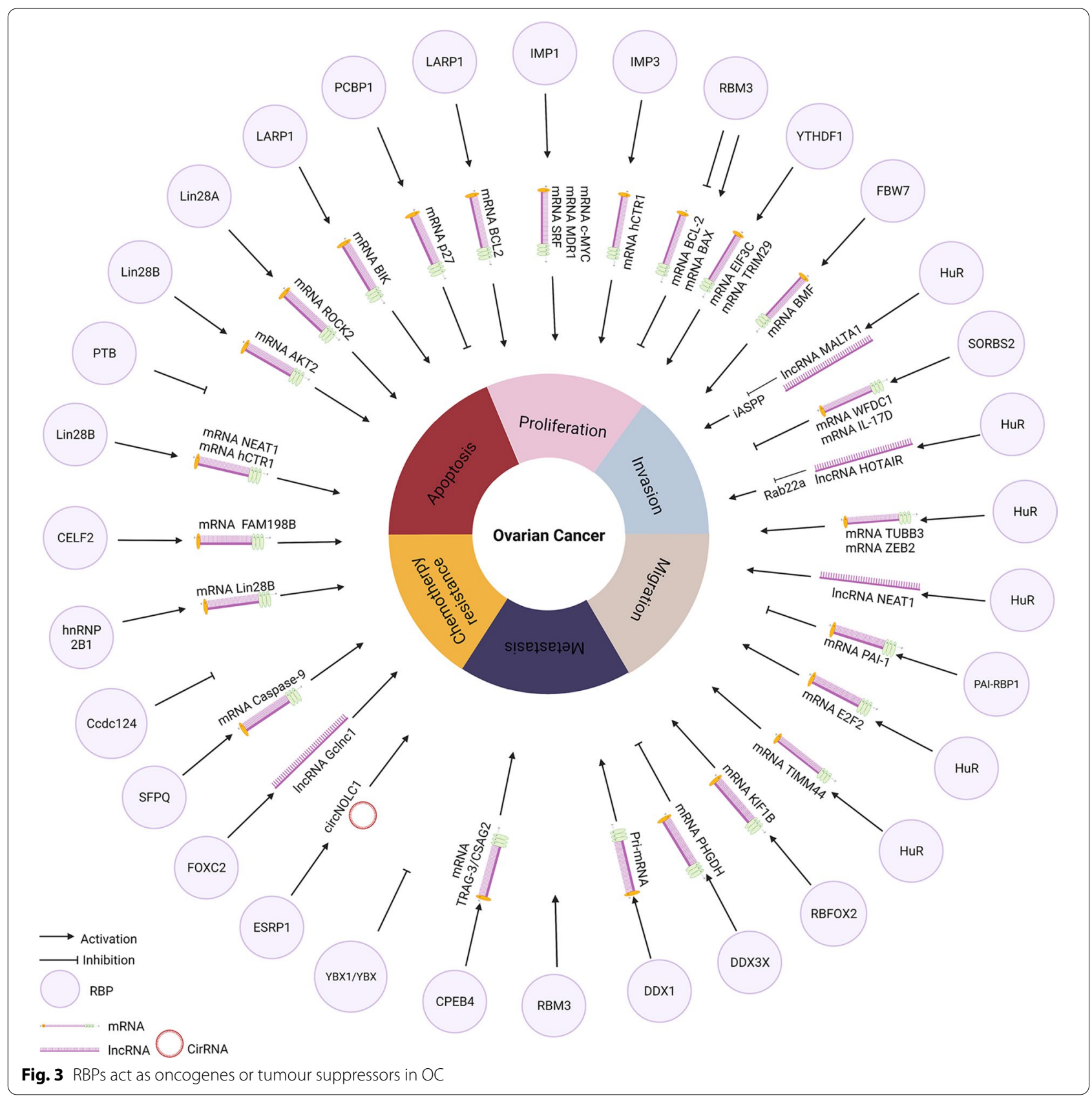

\section{Apoptosis}

Lin28 has two paralogues, Lin28A and Lin28B. Lin28A positively binds to and upregulates the mRNA encoding Rho-associated coiled-coil containing protein kinase family 2 (ROCK2) and therefore promotes cell proliferation, invasion, and metastasis and inhibits apoptosis in OC cells [84]. LIN28B is highly expressed in HGSOC and can inhibit OC cell apoptosis by binding to AKT2 mRNA, which is associated with the DNA damage pathway, and promote its expression, regulate FOXO3A protein phosphorylation and decrease the antiapoptotic activity of BIM [85]. NEAT1 is an abundant lncRNA that has been demonstrated to be an oncogene in multiple cancers. Lin28B enhances the stability of NEAT1, whose expression is upregulated in OC cells and correlated with poor prognosis [86].

PTB, a member of the heterogeneous nuclear family (hnRNPI), regulates RNA processing and internal ribosome entry (IRES)-mediated translation [87]. PTB 
knockdown in OC cells inhibits cell apoptosis by alternative splicing [88].

\section{Invasion and epithelial-mesenchymal transcription (EMT)}

Studies have revealed that IGF2BP1 can promote SRF expression in an M6A-dependent manner by impairing miRNA-directed decay [89]. These phenomena promote tumour cell growth and invasion in an SRF-dependent manner. Decreased IGF2BP2 levels significantly inhibit the proliferation of OC cells [90].

LncRNA HOX Transcript Antisense RNA (HOTAIR) is overexpressed in OC, leading to disease progression. HuR binds to the IncRNA HOTAIR, which positively regulates microRNA-373 expression and derepresses the expression of the Ras oncogene family member Rab22a, leading to the promotion of proliferation, migration and invasion [91]. It can induce paclitaxel resistance by binding to and stabilizing the mRNA encoding TUBB3 (class III b $\beta$-tubulin) in competition with miR-200c [92]. In OVCAR3 OC cells, HuR is highly overexpressed, and it binds to and stabilizes lncRNA nuclear enriched abundant transcript 1 (NEAT1), thereby positively promoting proliferation and invasion [46]. In addition, HuR contributes to tumour proliferation, migration and tumorigenicity by binding to the lncRNA metastasis-associated lung adenocarcinoma transcript 1 (MALAT1), which acts as a sponge for miR-506 and depresses the apoptosis inhibitor iASPP [93].

Gastric cancer-associated lncRNA1 (GClnc1) is a long noncoding RNA that plays an indispensable role in metastasis [94]. Forkhead box protein C2 (FOXC2) activates transcription of NOTCH1 by binding to GClnc1, thereby enhancing proliferation and EMT in OC cells [95].

Metastasis-associated lung adenocarcinoma transcript 1 (MALAT1) is a lncRNA whose expression is upregulated in $\mathrm{OC}$ and correlated with metastasis. Knockdown of MALAT1 expression can downregulate the splicing factor RBP Fox-1 Homologue 2 (RBFOX2) and subsequently regulate the transcription of tumour suppressor Kinesin family member 1B (KIF1B) [96].

Sorbin and SH3 domain-containing 2 (SORBS2), which is localized to the $4 \mathrm{q} 35$ region of the human genome, participates in signal transduction and cytoskeleton establishment [97]. Suppression of SORBS2 promotes cell migration by contributing to pseudopodia elongation and detachment of actin from focal adhesion areas [98]. SORBS2 can stabilize the tumour-suppressive immunomodulatory transcripts WAP four-disulfide core domain 1 (WFDC1) and interleukin-17D (IL-17D), thereby suppressing metastatic colonization of OC cells [99].
Our recent study indicates that CELF2 expression is positively correlated with the OS and PFS of OC patients. CELF2 increases the stability of its downstream target FAM198B by binding to AU/U-rich elements (AREs) in the 3' UTR, modulating the proliferation, migration and invasion of $\mathrm{OC}$ cells in vivo and in vitro. In addition, we also demonstrate that CELF2/FAM198B can repress the progression of $\mathrm{OC}$ via its effects on mitogen-activated protein kinase/extracellular-regulated protein kinase (MAPK/ERK) signalling [10].

Quaking isoforms 5 (QKI5) had been implicated in the processing of microRNA (miRNA) and pre-mRNA and was downregulated in several cancers, including SOC. Studies have also demonstrated that QKI5 could inhibit metastasis by targeting transcriptional coactivator PDZ (TAZ). Mechanistically, QKI5 bound to TAZ mRNA and recruited EDC4, thus decreasing the stability of TAZ mRNA [100].

\section{Chemotherapy resistance}

IGF2BP1 regulates chemoresistance in OC by stabilizing c-MYC and adenosine triphosphate (ATP)-dependent efflux pump MDR1 (multi-drug-resistance factor 1) [101].

Lin28B induces chemoresistance, and is correlated with a poor prognosis in HGSOC patients, by targeting downstream human copper transporter 1 (hCTR1) [70].

SFPQ (PSF, polypyrimidine tract binding protein-associated splicing factor) is a splicing factor that participates in the processes of RNA transport and apoptosis [102]. SFPQ knockdown increases platinum plus taxane-based chemotherapy (PT)-induced apoptosis by regulating alterative splicing of caspase-9 mRNA in EOC cells [103].

Cytoplasmic polyadenylation element binding protein 4 (CPEB4) has already been proven to be an RBP that contributes to transcript-level polyadenylation and translation. It binds to Taxol (paclitaxel)-resistance-associated gene-3 (TRAG-3/CSAG2), contributes to its translation, and promotes paclitaxel resistance in OC patients [104]. CSAG2 was demonstrated necessary for proliferation and tumorigenesis in vivo and CSAG2-stimulated SIRT1 activity to enhance p53 deacetylation was shown to inhibit p53 transcriptional activity, leading to improved cell survival under genotoxic stress [105]. Thus, interfering CPEB4/CSAG2 axis might be of benefit to overcome paclitaxel-resistant OC.

Y-box binding protein 1 (YBX1/YB1), a member of the cold-shock domain-containing protein family, positively regulates resistance to cisplatin and correlates with the prognosis of EOC patients [106].

RNA-binding motif protein 3 (RBM3) is associated with a favourable prognosis of $\mathrm{OC}$ patients and has been verified to be a positive predictor of overall survival 
(OS) and relapse-free survival (RFS) [107]. In addition, increased RBM3 expression promotes platinum sensitivity by regulating the apoptosis-related mediators BCL2, BAX and DNA integrity, which are involved in DNA damage, and repairs adverse cytotoxic effects after chemotherapy [3].

\section{Others}

Liang et al. have identified 3 significantly increased key RBPs (MRPL14, PARP4 [108] and STRAP [109]) and 3 markedly decreased RBPs (MRPL46 [110], LUC7L2 [111] and PAPOLA) related to OC by bioinformatics analysis, and subsequently verified in OC tissues by immunohistochemistry and RNA-seq data [90]. Fortunately, it is not clear how these RBPs are related to the mechanism of $\mathrm{OC}$ formation.

\section{The role of RBPs as potential diagnostic, prognostic and therapeutic biomarkers in $\mathrm{OC}$}

Most OC patients present with advanced abdominal pelvic metastasis and surgically unresectable disease due to a lack of reliable and valid diagnostic markers. Therefore, the early diagnosis of $\mathrm{OC}$ is important and is associated with a significant improvement in prognosis $[64,112]$.

To date, several studies have confirmed the diagnostic and prognostic roles of RBPs in different cancers, including OC [113-116]. For example, IGF2BP1 expression is mostly upregulated and correlated with poor prognosis in OC [52]. Consistently, another study using gene set enrichment analysis (GSEA) revealed that IGF2BP1 is associated with pathways and WNT signalling pathways [117]. In addition, the expression of another family member, IGF2BP3, is associated with more invasive phenotypes and poor survival rates [70]. More relevant studies are needed in the future to confirm its role as a potential diagnostic and prognostic biomarker in OC.

Next, we will review many potential therapeutic biomarkers, including antisense oligonucleotides (ASOs), small peptides, and small molecule inhibitors. In OC, 4EBP-based peptides can prevent cap-dependent translation by binding to the eIF4E factor, ultimately repressing tumour progression. They can bind to an analogue of gonadotropin-releasing hormone $(\mathrm{GnRH})$, which is expressed in the majority of OC patients and has anticancer effects [118]. The synthetic peptide can prevent tumour progression without any cytotoxicity in a xenograft model of OC. In addition, fusion peptides can inhibit tumour growth by disrupting the RBM38-eIF4E interaction and thus upregulating the P53 levels with the goal of inhibiting tumour progression in vivo and in vitro [119]. Collectively, these findings support that the fusion peptide complex may be a potential therapeutic agent. In addition, microsatellite instability (MSI) is highly expressed in $\mathrm{OC}$, and this high expression is associated with poor prognosis of OC patients. MSI siRNAs may be a new therapeutic strategy for reversing resistance and repressing OC tumours [120]. More relevant clinical studies are needed in the future to confirm its role as a therapeutic biomarker in OC.

\section{Influences of RBPs on regulating OC cellular signalling pathways}

Although an increasing number of RBPs have been identified and verified, their posttranscriptional gene regulation (PTGR) signalling pathways have not been fully elucidated. It is now understood that RBPs involved in PTGR can cooperate with ncRNAs to bind to mRNAs and modify the amounts of proteins generated [5]. RBM11 can positively regulate the Akt/mTOR signalling pathway in OC cells [121]. Our previous studies have demonstrated that CELF2/FAM198B can repress the progression of OC via MAPK/ERK signalling and further be used to target the ERK pathway in the future [10]. Overexpression of LIN28B inhibits OC in vitro through regulation of the AKT2/FOXO3A/BIM axis [85]. MSI-1 effectively protects $\mathrm{OC}$ cells against paclitaxel treatment by ERK signalling pathway activation [120]. IGF2BP2 enhances circ0000745 and promotes aggressiveness and stemness in OC via miR-3187-3p/ERBB4/PI3K/ AKT axis [122]. By TCGA analysis, down-regulation of RAD51AP1 (RAD51-dependent homologous recombination) supressed proliferation, migration and invasion of OC cells and correlated with TGF- $\beta /$ Smad pathway [123]. Under platinum and paclitaxel (PT) treatment, SFPQ/p54 ${ }^{\text {nrb }} /$ SRSF2 pathway plays a crucial role in OC resistance [103].

\section{Future perspectives and conclusions}

Due to the late diagnosis and high rate of relapse, OC patients have poor prognosis, and its specific pathogenesis of OC is still unclear. Therefore, it is of outer importance to identify earlier diagnostic and more efficient therapeutic approaches for clinical application of OC. Currently, increasing evidence reveals that changes in RBP expression affect multiple steps of OC progression. In this review, RBPs were revealed to participate in multiply biological processes of $\mathrm{OC}$ and can serve as promising biomarkers for the diagnosis, prognosis, and therapy of OC. At present, a few studies have already provided proof-of-concept evidence regarding the in vitro use of small-molecule inhibitors, therapeutic peptides or ASOs to selectively antagonize RBPs or RBP-RNA interactions, as verified by experiments using eIF4E, MSI, and LIN28, which have shown favourable functional outcomes [118-120, 124]. Nevertheless, whether RBPs can successfully act as effective 
biomarkers for the diagnosis, prognosis and therapy of OC is still far from clinical application. The application of specific RBPs related to human disease in the treatment of tumours is the ultimate goal of RBP-related research.

Therefore, some suggestions are put forward for future research on RBPs in OC. Firstly, although many researchers have initially demonstrated some mechanisms of RBPs' dysregulated expression. More scientific researches and explorations are indispensable needed to fully clarify the mechanism of biogenesis of RBPs. A complete annotation of RBP dysregulated expression will undoubtedly enhance our understanding of its function. Secondly, RBPs exert their functions by binding to downstream RNA, forming RNP complexes and subsequently regulate the functions of RNA transcripts via multiple posttranscriptional mechanisms. Even small alterations in the expression can cause significant changes in regulatory networks. Therefore, it is imperative to elucidate other further mechanisms that we do not know. Thirdly, the detection of RBPs is currently mainly applied in tumor tissues. Thus, the expression of RBPs should be detected in more clinical samples, such as blood, urine. Combined detection methods should be exploited to obtain more diagnostic values. Fox example, special RBPs could be combined with traditional detection markers to improve the sensitivity and specificity of disease diagnosis. Fourthly, how to deliver RBPs to the tumour sites of the body, how to avoid the immune responses, how to ensure stable and effective function are difficult problems that need be addressed urgently.

In summary, our current understanding of RBP functions in $\mathrm{OC}$ is still very limited. Fortunately, with the accelerated development of biotechnology and bioinformatics analyses, more RBPs will be discovered and validated. In the near future, we believe that in-depth knowledge of RBPs and effective application of RBPs in clinical practice will represent a giant breakthrough in the treatment of OC.

\section{Acknowledgements}

We thank the editors at AJE (American Journal Experts) for their help in editing the manuscript.

\section{Authors' contributions \\ JCW: Conceptualization, Data curation, Investigation, Writing—original draft. Y W: Conceptualization, Data curation, Investigation, Writing - original draft, Formal analysis, Methodology, Resources, Software, Validation, Visualization. QH G: Conceptualization, Project administration, Supervision, Writing—origi- nal draft. SM W: Conceptualization, Funding acquisition, Project administra- tion, Supervision, Writing —original draft, Writing - review and editing. XH W: Conceptualization, Funding acquisition, Project administration, Supervision, Writing - original draft, Writing — review and editing. All authors read and approved the final manuscript.}

\section{Funding}

This work was supported, in part, by grants from the National Natural Science Foundation of China (Numbers 81972431, 82002747); Shanghai Sailing
Program (Number 20YF1408000); and Shanghai Anticancer Association EYAS PROJECT (Number SACA-CY19A07).

Data availability

Not applicable.

\section{Declarations}

Ethics approval and consent to participate

This review article does not contain studies with human participants or animals performed by any of the authors.

\section{Informed consent}

Not applicable.

\section{Competing interests}

The authors declare no conflict of interest.

\section{Author details}

${ }^{1}$ Department of Oncology, Shanghai Medical College, Fudan University, Shanghai 200032, China. ${ }^{2}$ Department of Gynecologic Oncology, Fudan University Shanghai Cancer Center, Fudan University, Shanghai 200032, People's Republic of China.

Received: 19 October 2021 Accepted: 11 January 2022

Published online: 21 January 2022

\section{References}

1. Siegel RL, Miller KD, Fuchs HE, Jemal A. Cancer Statistics. CA Cancer J Clin. 2021;71(2021):7-33. https://doi.org/10.3322/caac.21654.

2. Matulonis UA, Sood AK, Fallowfield L, Howitt BE, Sehouli J, Karlan BY. Ovarian cancer. Nat Rev Dis Primers. 2016;2:16061. https://doi.org/10. 1038/nrdp.2016.61.

3. Blagden S, Abdel Mouti M, Chettle J. Ancient and modern: hints of a core post-transcriptional network driving chemotherapy resistance in ovarian cancer. Wiley Interdiscip Rev RNA. 2018. https://doi.org/10. 1002/wrna.1432.

4. Narod S. Can advanced-stage ovarian cancer be cured? Nat Rev Clin Oncol. 2016;13:255-61. https://doi.org/10.1038/nrclinonc.2015.224.

5. Jayson GC, Kohn EC, Kitchener HC, Ledermann JA. Ovarian cancer. Lancet. 2014;384:1376-88. https://doi.org/10.1016/S0140-6736(13) 62146-7.

6. Mohibi S, Chen X, Zhang J. Cancer the'RBP'eutics-RNA-binding proteins as therapeutic targets for cancer. Pharmacol Ther. 2019;203:107390. https://doi.org/10.1016/j.pharmthera.2019.07.001.

7. Busa R, Paronetto MP, Farini D, Pierantozzi E, Botti F, Angelini DF, Attisani F, Vespasiani G, Sette C. The RNA-binding protein Sam68 contributes to proliferation and survival of human prostate cancer cells. Oncogene. 2007;26:4372-82. https://doi.org/10.1038/sj.onc.1210224.

8. Yang G, Fu H, Zhang J, Lu X, Yu F, Jin L, Bai L, Huang B, Shen L, Feng Y, Yao L, Lu Z. RNA-binding protein quaking, a critical regulator of colon epithelial differentiation and a suppressor of colon cancer. Gastroenterology. 2010;138(231-240):e231-235. https://doi.org/10.1053/j.gastro. 2009.08.001.

9. Janiszewska M, Suva ML, Riggi N, Houtkooper RH, Auwerx J, ClementSchatlo V, Radovanovic I, Rheinbay E, Provero P, Stamenkovic I. Imp2 controls oxidative phosphorylation and is crucial for preserving glioblastoma cancer stem cells. Genes Dev. 2012;26:1926-44. https://doi. org/10.1101/gad.188292.112.

10. Guo Q, Wu Y, Guo X, Cao L, Xu F, Zhao H, Zhu J, Wen H, Ju X, Wu X. The RNA-Binding Protein CELF2 Inhibits Ovarian Cancer Progression by Stabilizing FAM198B. Mol Ther Nucleic Acids. 2021;23:169-84. https:// doi.org/10.1016/j.omtn.2020.10.011.

11. Sternburg EL, Karginov FV. Global approaches in studying rna-binding protein interaction networks. Trends Biochem Sci. 2020;45:593-603. https://doi.org/10.1016/j.tibs.2020.03.005. 
12. Pereira B, Billaud M, Almeida R. RNA-binding proteins in cancer: old players and new actors, trends. Cancer. 2017;3:506-28. https://doi.org/ 10.1016/j.trecan.2017.05.003.

13. Zhou M, Wang X, Shi H, Cheng L, Wang Z, Zhao H, Yang L, Sun J. Characterization of long non-coding RNA-associated ceRNA network to reveal potential prognostic IncRNA biomarkers in human ovarian cancer. Oncotarget. 2016;7:12598-611. https://doi.org/10.18632/oncotarget. 7181.

14. Sebestyen E, Singh B, Minana B, Pages A, Mateo F, Pujana MA, Valcarcel J, Eyras E. Large-scale analysis of genome and transcriptome alterations in multiple tumors unveils novel cancer-relevant splicing networks. Genome Res. 2016;26:732-44. https://doi.org/10.1101/gr.199935.115.

15. Bai Y, Qiu GR, Zhou F, Gong LY, Gao F, Sun KL. Overexpression of DICER1 induced by the upregulation of GATA1 contributes to the proliferation and apoptosis of leukemia cells. Int J Oncol. 2013;42:1317-24. https:// doi.org/10.3892/ijo.2013.1831.

16. Abdelmohsen K, Tominaga-Yamanaka K, Srikantan S, Yoon JH, Kang MJ, Gorospe M. RNA-binding protein AUF1 represses Dicer expression. Nucleic Acids Res. 2012;40:11531-44. https://doi.org/10.1093/nar/ gks930.

17. Castello A, Fischer B, Eichelbaum K, Horos R, Beckmann BM, Strein C, Davey NE, Humphreys DT, Preiss T, Steinmetz LM, Krijgsveld J, Hentze MW. Insights into RNA biology from an atlas of mammalian mRNAbinding proteins. Cell. 2012;149:1393-406. https://doi.org/10.1016/j.cell. 2012.04.031.

18. He Q, Zhao L, Liu X, Zheng J, Liu Y, Liu L, Ma J, Cai H, Li Z, Xue Y. MOV10 binding circ-DICER1 regulates the angiogenesis of glioma via miR103a-3p/miR-382-5p mediated ZIC4 expression change. J Exp Clin Cancer Res. 2019;38:9. https://doi.org/10.1186/s13046-018-0990-1.

19. Selvanathan SP, Graham GT, Erkizan HV, Dirksen U, Natarajan TG, Dakic A, Yu S, Liu X, Paulsen MT, Ljungman ME, Wu CH, Lawlor ER, Uren A, Toretsky JA. Oncogenic fusion protein EWS-FLI1 is a network hub that regulates alternative splicing. Proc Natl Acad Sci U S A. 2015;112:E13071316. https://doi.org/10.1073/pnas.1500536112.

20. Larsen JE, Nathan V, Osborne JK, Farrow RK, Deb D, Sullivan JP, Dospoy PD, Augustyn A. ZEB1 drives epithelial-to-mesenchymal transition in lung cancer. J Clin Invest. 2016;126:3219-35.

21. Krebs AM, Mitschke J, Lasierra Losada M, Schmalhofer O, Boerries M, Busch H, Boettcher M, Mougiakakos D, Reichardt W, Bronsert P, Brunton VG, Pilarsky C, Winkler TH, Brabletz S, Stemmler MP, Brabletz T. The EMTactivator Zeb1 is a key factor for cell plasticity and promotes metastasis in pancreatic cancer. Nat Cel Biol. 2017;19:518-29. https://doi.org/10. 1038/ncb3513.

22. Zhang J, Cho SJ, Shu L, Yan W, Guerrero T, Kent M, Skorupski K, Chen H, Chen X. Translational repression of p53 by RNPC1, a p53 target overexpressed in lymphomas. Genes Dev. 2011;25:1528-43. https://doi.org/10. 1101/gad.2069311.

23. Zhang J, Jun S, Chen X. RNPC1, an RNA-binding protein and a target of the p53 family, regulates p63 expression through mRNA stability. Proc Natl Acad Sci USA. 2010;107:9614-9. https://doi.org/10.1073/pnas. 0912594107.

24. Abdelmohsen K, Kim MM, Srikantan S, Mercken EM, Brennan SE, Wilson GM, Cabo R, Gorospe M. miR-519 suppresses tumor growth by reducing HuR levels. Cell Cycle. 2010;9:1354-9. https://doi.org/10.4161/cc.9.7. 11164.

25. Gao J, Dai C, Yu X, Yin XB, Zhou F. Long noncoding RNA LEF1-AS1 acts as a microRNA-10a-5p regulator to enhance MSI1 expression and promote chemoresistance in hepatocellular carcinoma cells through activating AKT signaling pathway. J Cell Biochem. 2021;122:86-99. https://doi.org/10.1002/jcb.29833.

26. Yang LY, Song GL, Zhai XQ, Wang L, Liu QL, Zhou MS. MicroRNA-331 inhibits development of gastric cancer through targeting musashi1, World J Gastrointest. Oncol. 2019;11:705-16. https://doi.org/10.4251/ wjgo.v11.i9.705.

27. Brown AS, Mohanty BK, Howe PH. Identification and characterization of an hnRNP E1 translational silencing motif. Nucleic Acids Res. 2016;44:5892-907. https://doi.org/10.1093/nar/gkw241.

28. Chaudhury A, Hussey GS, Ray PS, Jin G, Fox PL, Howe PH. TGF-betamediated phosphorylation of hnRNP E1 induces EMT via transcriptselective translational induction of Dab2 and ILEI. Nat Cell Biol. 2010;12:286-93. https://doi.org/10.1038/ncb2029.
29. Babic I, Jakymiw A, Fujita DJ. The RNA binding protein Sam68 is acetylated in tumor cell lines, and its acetylation correlates with enhanced RNA binding activity. Oncogene. 2004;23:3781-9. https://doi.org/10. 1038/sj.onc.1207484.

30. Neelamraju Y, Hashemikhabir S, Janga SC. The human RBPome: from genes and proteins to human disease. J Proteomics. 2015;127:61-70. https://doi.org/10.1016/j.jprot.2015.04.031.

31. Gerstberger S, Hafner M, Tuschl T. A census of human RNA-binding proteins. Nat Rev Genet. 2014;15:829-45. https://doi.org/10.1038/nrg38 13.

32. Lunde BM, Moore C, Varani G. RNA-binding proteins: modular design for efficient function. Nat Rev Mol Cell Biol. 2007;8:479-90. https://doi. org/10.1038/nrm2178.

33. Nishikura K. Functions and regulation of RNA editing by ADAR deaminases. Annu Rev Biochem. 2010;79:321-49. https://doi.org/10.1146/ annurev-biochem-060208-105251.

34. Moore S, Jarvelin Al, Davis I, Bond GL, Castello A. Expanding horizons: new roles for non-canonical RNA-binding proteins in cancer. Curr Opin Genet Dev. 2018;48:112-20. https://doi.org/10.1016/j.gde.2017.11.006.

35. Kang $D$, Lee $Y$, Lee JS. RNA-binding proteins in cancer: functional and therapeutic perspectives. Cancers (Basel). 2020. https://doi.org/10. 3390/cancers12092699.

36. Corley M, Burns MC, Yeo GW. How RNA-Binding Proteins Interact with RNA: Molecules and Mechanisms. Mol Cell. 2020;78:9-29. https://doi. org/10.1016/j.molcel.2020.03.011.

37. Scotti MM, Swanson MS. RNA mis-splicing in disease. Nat Rev Genet. 2016;17:19-32. https://doi.org/10.1038/nrg.2015.3.

38. Baralle FE, Giudice J. Alternative splicing as a regulator of development and tissue identity. Nat Rev Mol Cell Biol. 2017;18:437-51. https://doi. org/10.1038/nrm.2017.27.

39. Singh RK, Cooper TA. Pre-mRNA splicing in disease and therapeutics. Trends Mol Med. 2012;18:472-82. https://doi.org/10.1016/j.molmed. 2012.06.006.

40. Anko ML. Regulation of gene expression programmes by serine-arginine rich splicing factors. Semin Cell Dev Biol. 2014;32:11-21. https:// doi.org/10.1016/j.semcdb.2014.03.011.

41. Muller-McNicoll M, Botti $V$, de JesusDomingues AM, Brandl $H$, Schwich OD, Steiner MC, Curk T, Poser I, Zarnack K, Neugebauer KM. SR proteins are NXF1 adaptors that link alternative RNA processing to mRNA export. Genes Dev. 2016;30:553-66. https://doi.org/10.1101/gad.276477.115.

42. Ortiz-Zapater E, Pineda D, Martinez-Bosch N, Fernandez-Miranda G, Iglesias M, Alameda F, Moreno M, Eliscovich C, Eyras E, Real FX, Mendez R, Navarro P. Key contribution of CPEB4-mediated translational control to cancer progression. Nat Med. 2011;18:83-90. https://doi.org/10. 1038/nm.2540

43. Lazzaretti D, Bono F. mRNA localization in metazoans: A structural perspective. RNA Biol. 2017;14:1473-84. https://doi.org/10.1080/15476 286.2017.1338231.

44. Nagaoka K, Fujii K, Zhang H, Usuda K, Watanabe G, Ivshina M, Richter JD CPEB1 mediates epithelial-to-mesenchyme transition and breast cance metastasis. Oncogene. 2016;35:2893-901. https://doi.org/10.1038/onc. 2015.350.

45. Nagaoka K, Udagawa T, Richter JD. CPEB-mediated ZO-1 mRNA localization is required for epithelial tight-junction assembly and cell polarity. Nat Commun. 2012;3:675. https://doi.org/10.1038/ncomms1678.

46. Chai Y, Liu J, Zhang Z, Liu L. HuR-regulated IncRNA NEAT1 stability in tumorigenesis and progression of ovarian cancer. Cancer Med. 2016;5:1588-98. https://doi.org/10.1002/cam4.710.

47. Wang J, Guo Y, Chu H, Guan Y, Bi J, Wang B. Multiple functions of the RNA-binding protein HuR in cancer progression, treatment responses and prognosis. Int J Mol Sci. 2013;14:10015-41. https://doi.org/10.3390/ ijms140510015.

48. Sakuma T, Nakagawa T, Ido K, Takeuchi H, Sato K, Kubota T. Expression of vascular endothelial growth factor-A and mRNA stability factor HuR in human meningiomas. J Neurooncol. 2008;88:143-55. https://doi.org/ 10.1007/s11060-008-9559-8.

49. Mayr C. Regulation by 3'-Untranslated Regions. Annu Rev Genet. 2017;51:171-94. https://doi.org/10.1146/annur ev-genet-120116-024704.

50. Lal A, Mazan-Mamczarz K, Kawai T, Yang X, Martindale JL, Gorospe M. Concurrent versus individual binding of HuR and AUF1 to common 
labile target mRNAs. EMBO J. 2004;23:3092-102. https://doi.org/10. 1038/sj.emboj.7600305.

51. Kessler SM, Lederer E, Laggai S, Golob-Schwarzl N, Hosseini K, Petzold J, Schweiger C, Reihs R, Keil M, Hoffmann J, Mayr C, Kiesslich T, Pichler M, Kim KS, Rhee H, Park YN, Lax S, Obrist P, Kiemer AK, Haybaeck J. IMP2/ IGF2BP2 expression, but not IMP1 and IMP3, predicts poor outcome in patients and high tumor growth rate in xenograft models of gallbladder cancer. Oncotarget. 2017;8:89736-45. https://doi.org/10.18632/ oncotarget.21116.

52. Bell JL, Wachter K, Muhleck B, Pazaitis N, Kohn M, Lederer M, Huttelmaier S. Insulin-like growth factor 2 mRNA-binding proteins (IGF2BPs): post-transcriptional drivers of cancer progression? Cell Mol Life Sci. 2013;70:2657-75. https://doi.org/10.1007/s00018-012-1186-z.

53. Medjkane S, Perez-Sanchez C, Gaggioli C, Sahai E, Treisman R. Myocardin-related transcription factors and SRF are required for cytoskeletal dynamics and experimental metastasis. Nat Cell Biol. 2009;11:257-68. https://doi.org/10.1038/ncb1833.

54. Kobel M, Weidensdorfer D, Reinke C, Lederer M, Schmitt WD, Zeng K, Thomssen C, Hauptmann S, Huttelmaier S. Expression of the RNA-binding protein IMP1 correlates with poor prognosis in ovarian carcinoma. Oncogene. 2007;26:7584-9. https://doi.org/10.1038/sj.onc.1210563.

55. Liao S, Sun H, Xu C, Domain YTH. A Family of N(6)-methyladenosine (m(6)A) Readers. Genomics Proteomics Bioinformatics. 2018;16:99-107. https://doi.org/10.1016/j.gpb.2018.04.002.

56. Liu T, Wei Q, Jin J, Luo Q, Liu Y, Yang Y, Cheng C, Li L, Pi J, Si Y, Xiao H, Li L, Rao S, Wang F, Yu J, Yu J, Zou D, Yi P. The m6A reader YTHDF1 promotes ovarian cancer progression via augmenting EIF3C translation. Nucleic Acids Res. 2020;48:3816-31. https://doi.org/10.1093/nar/gkaa048.

57. Hatakeyama S. TRIM proteins and cancer. Nat Rev Cancer. 2011;11:792804. https://doi.org/10.1038/nrc3139.

58. Xu F, Li J, Ni M, Cheng J, Zhao H, Wang S, Zhou X, Wu X. FBW7 suppresses ovarian cancer development by targeting the N(6)-methyladenosine binding protein YTHDF2. Mol Cancer. 2021;20:45. https://doi. org/10.1186/s12943-021-01340-8.

59. Elloul S, Elstrand MB, Nesland JM, Trope CG, Kvalheim G, Goldberg I, Reich R, Davidson B. Snail, Slug, and Smad-interacting protein 1 as novel parameters of disease aggressiveness in metastatic ovarian and breast carcinoma. Cancer. 2005;103:1631-43. https://doi.org/10.1002/ cncr.20946.

60. Prislei S, Martinelli E, Zannoni GF, Petrillo M, Filippetti F, Mariani M, Mozzetti S, Raspaglio G, Scambia G, Ferlini C. Role and prognostic significance of the epithelial-mesenchymal transition factor ZEB2 in ovarian cancer. Oncotarget. 2015;6:18966-79. https://doi.org/10.18632/ oncotarget.3943.

61. Wang Y, Katayama A, Terami T, Han X, Nunoue T, Zhang D, Teshigawara S, Eguchi J, Nakatsuka A, Murakami K, Ogawa D, Furuta Y, Makino H, Wada J. Translocase of inner mitochondrial membrane 44 alters the mitochondrial fusion and fission dynamics and protects from type 2 diabetes. Metabolism. 2015;64:677-88. https://doi.org/10.1016/j.metab ol.2015.02.004.

62. Yu X, Li Y, Ding Y, Zhang H, Ding N, Lu M. HuR promotes ovarian cancer cell proliferation by regulating TIMM44 mRNA Stability. Cell Biochem Biophys. 2020;78:447-53. https://doi.org/10.1007/s12013-020-00939-w.

63. Chen HZ, Tsai SY, Leone G. Emerging roles of E2Fs in cancer: an exit from cell cycle control. Nat Rev Cancer. 2009;9:785-97. https://doi.org/ 10.1038/nrc2696.

64. Zhang M, Xu Y, Zhang Y, Li B, Lou G. Circular RNA circE2F2 promotes malignant progression of ovarian cancer cells by upregulating the expression of E2F2 protein via binding to HuR protein. Cell Signal. 2021;84: 110014. https://doi.org/10.1016/j.cellsig.2021.110014.

65. Fonseca BD, Zakaria C, Jia JJ, Graber TE, Svitkin Y, Tahmasebi S, Healy D, Hoang HD, Jensen JM, Diao IT, Lussier A, Dajadian C, Padmanabhan N, Wang W, Matta-Camacho E, Hearnden J, Smith EM, Tsukumo Y, Yanagiya A, Morita M, Petroulakis E, Gonzalez JL, Hernandez G, Alain T, Damgaard CK. La-related Protein 1 (LARP1) Represses Terminal Oligopyrimidine (TOP) mRNA Translation Downstream of mTOR Complex 1 (mTORC 1). J Biol Chem. 2015;290:15996-6020. https://doi.org/10.1074/jbc.M114. 621730.

66. Mura M, Hopkins TG, Michael T, Abd-Latip N, Weir J, Aboagye E, Mauri F, Jameson C, Sturge J, Gabra H, Bushell M, Willis AE, Curry E, Blagden SP. LARP1 post-transcriptionally regulates mTOR and contributes to cancer progression. Oncogene. 2015;34:5025-36. https://doi.org/10.1038/onc. 2014.428.

67. Hopkins TG, Mura M, Al-Ashtal HA, Lahr RM, Abd-Latip N, Sweeney K, Lu H, Weir J, El-Bahrawy M, Steel JH, Ghaem-Maghami S, Aboagye EO, Berman AJ, Blagden SP. The RNA-binding protein LARP1 is a post-transcriptional regulator of survival and tumorigenesis in ovarian cancer. Nucleic Acids Res. 2016;44:1227-46. https://doi.org/10.1093/nar/gkv15 15.

68. Geuens T, Bouhy D, Timmerman V. The hnRNP family: insights into their role in health and disease. Hum Genet. 2016;135:851-67. https://doi. org/10.1007/s00439-016-1683-5.

69. Yang Y, Wei Q, Tang Y, Yuanyuan W, Luo Q, Zhao H, He M, Wang H, Zeng Q, Lu W, Xu J, Liu T, Yi P. Loss of hnRNPA2B1 inhibits malignant capability and promotes apoptosis via down-regulating Lin28B expression in ovarian cancer. Cancer Lett. 2020;475:43-52. https://doi.org/10.1016/j. canlet.2020.01.029.

70. Hsu KF, Shen MR, Huang YF, Cheng YM, Lin SH, Chow NH, Cheng SW, Chou $\mathrm{CY}, \mathrm{Ho} \mathrm{CL}$. Overexpression of the RNA-binding proteins Lin28B and IGF2BP3 (IMP3) is associated with chemoresistance and poor disease outcome in ovarian cancer. Br J Cancer. 2015;113:414-24. https:// doi.org/10.1038/bjc.2015.254.

71. Warzecha CC, Sato TK, Nabet B, Hogenesch JB, Carstens RP. ESRP1 and ESRP2 are epithelial cell-type-specific regulators of FGFR2 splicing. Mol Cell. 2009;33:591-601. https://doi.org/10.1016/j.molcel.2009.01.025.

72. Chen S, Wu W, Li QH, Xie BM, Shen F, Du YP, Zong ZH, Wang LL, Wei XQ, Zhao Y. Circ-NOLC1 promotes epithelial ovarian cancer tumorigenesis and progression by binding ESRP1 and modulating CDK1 and RhoA expression. Cell Death Discov. 2021;7:22. https://doi.org/10.1038/ s41420-020-00381-0.

73. Gregory RI, Yan KP, Amuthan G, Chendrimada T, Doratotaj B, Cooch N, Shiekhattar R. The Microprocessor complex mediates the genesis of microRNAs. Nature. 2004;432:235-40. https://doi.org/10.1038/natur e03120.

74. Lee Y, Ahn C, Han J, Choi H, Kim J, Yim J, Lee J, Provost P, Radmark O, Kim $\mathrm{S}, \mathrm{Kim}$ VN. The nuclear RNase III Drosha initiates microRNA processing. Nature. 2003;425:415-9. https://doi.org/10.1038/nature01957.

75. Han C, Liu Y, Wan G, Choi HJ, Zhao L, Ivan C, He X, Sood AK, Zhang X, Lu $X$. The RNA-binding protein DDX1 promotes primary microRNA maturation and inhibits ovarian tumor progression. Cell Rep. 2014;8:1447-60. https://doi.org/10.1016/j.celrep.2014.07.058.

76. Li J, Wu L, Pei M, Zhang Y. YTHDF2, a protein repressed by miR-145, regulates proliferation, apoptosis, and migration in ovarian cancer cells. J Ovarian Res. 2020;13:111. https://doi.org/10.1186/s13048-020-00717-5.

77. Ehlen A, Nodin B, Rexhepaj E, Brandstedt J, Uhlen M, Alvarado-Kristensson M, Ponten F, Brennan DJ, Jirstrom K. RBM3-regulated genes promote DNA integrity and affect clinical outcome in epithelial ovarian cancer. Transl Oncol. 2011;4:212-21. https://doi.org/10.1593/tlo.11106.

78. Shi H, Li H, Yuan R, Guan W, Zhang X, Zhang S, Zhang W, Tong F, Li L, Song Z, Wang C, Yang S, Wang H. PCBP1 depletion promotes tumorigenesis through attenuation of p27(Kip1) mRNA stability and translation. J Exp Clin Cancer Res. 2018;37:187. https://doi.org/10.1186/ s13046-018-0840-1.

79. Arslan O, Soylu NK, Akillilar PT, Tazebay UH. Coiled-coil domain-containing protein-124 (Ccdc124) is a novel RNA binding factor up-regulated in endometrial, ovarian, and urinary bladder cancers. Cancer Biomark. 2021;31:149-64. https://doi.org/10.3233/CBM-200802.

80. Bi F, An Y, Sun T, You Y, Yang Q. PHGDH Is Upregulated at Translational Level and Implicated in Platin-Resistant in Ovarian Cancer Cells. Front Oncol. 2021;11: 643129. https://doi.org/10.3389/fonc.2021.643129.

81. Ni J, Chen L, Ling L, Wu M, Ren Q, Zhu W. MicroRNA-196a promotes cell proliferation and inhibits apoptosis in human ovarian cancer by directly targeting DDX3 and regulating the PTEN/PI3K/AKT signaling pathway. Mol Med Rep. 2020;22:1277-84. https://doi.org/10.3892/mmr.2020. 11236.

82. Andreasen PA, Kjoller L, Christensen L, Duffy MJ. The urokinase-type plasminogen activator system in cancer metastasis: a review. Int J Cancer. 1997;72:1-22. https://doi.org/10.1002/(sici)1097-0215(19970 703)72:1\%3c1::aid-ijc1\%3e3.0.co;2-z.

83. Koensgen D, Mustea A, Klaman I, Sun P, Zafrakas M, Lichtenegger W, Denkert C, Dahl E, Sehouli J. Expression analysis and RNA localization of PAI-RBP1 (SERBP1) in epithelial ovarian cancer: association with tumor 
progression. Gynecol Oncol. 2007;107:266-73. https://doi.org/10.1016/j. ygyno.2007.06.023.

84. Zhong Y, Yang S, Wang W, Wei P, He S, Ma H, Yang J, Wang Q, Cao L, Xiong W, Zhou M, Li G, Shuai C, Peng S. The interaction of Lin28A Rho associated coiled-coil containing protein kinase 2 accelerates the malignancy of ovarian cancer. Oncogene. 2019;38:1381-97. https://doi. org/10.1038/s41388-018-0512-9.

85. Lin X, Shen J, Dan P, He X, Xu C, Chen X, Tanyi JL, Montone K, Fan Y, Huang Q, Zhang L, Zhong X. RNA-binding protein LIN28B inhibits apoptosis through regulation of the AKT2/FOXO3A/BIM axis in ovarian cancer cells. Signal Transduct Target Ther. 2018;3:23. https://doi.org/10. 1038/s41392-018-0026-5.

86. Yong W, Yu D, Jun Z, Yachen D, Weiwei W, Midie X, Xingzhu J, Xiaohua W. Long noncoding RNA NEAT1, regulated by LIN28B, promotes cell proliferation and migration through sponging miR-506 in high-grade serous ovarian cancer. Cell Death Dis. 2018;9:861. https://doi.org/10. 1038/s41419-018-0908-z.

87. Wollerton MC, Gooding C, Wagner EJ, Garcia-Blanco MA, Smith CW. Autoregulation of polypyrimidine tract binding protein by alternative splicing leading to nonsense-mediated decay. Mol Cell. 2004;13:91100. https://doi.org/10.1016/s1097-2765(03)00502-1.

88. He X, Pool M, Darcy KM, Lim SB, Auersperg N, Coon JS, BeckWT. Knockdown of polypyrimidine tract-binding protein suppresses ovarian tumor cell growth and invasiveness in vitro. Oncogene. 2007;26:4961-8. https://doi.org/10.1038/sj.onc.1210307.

89. Muller S, Glass M, Singh AK, Haase J, Bley N, Fuchs T, Lederer M, Dahl A, Huang H, Chen J, Posern G, Huttelmaier S. IGF2BP1 promotes SRFdependent transcription in cancer in a m6A- and miRNA-dependent manner. Nucleic Acids Res. 2019;47:375-90. https://doi.org/10.1093/ nar/gky1012.

90. He C, Huang F, Zhang K, Wei J, Hu K, Liang M. Establishment and validation of an RNA binding protein-associated prognostic model for ovarian cancer. J Ovarian Res. 2021;14:27. https://doi.org/10.1186/ s13048-021-00777-1.

91. Zhang Z, Cheng J, Wu Y, Qiu J, Sun Y, Tong X. LncRNA HOTAIR controls the expression of Rab22a by sponging miR-373 in ovarian cancer. Mol Med Rep. 2016;14:2465-72. https://doi.org/10.3892/mmr.2016.5572.

92. Prislei S, Martinelli E, Mariani M, Raspaglio G, Sieber S, Ferrandina G, Shahabi S, Scambia G, Ferlini C. MiR-200c and HuR in ovarian cancer. BMC Cancer. 2013;13:72. https://doi.org/10.1186/1471-2407-13-72.

93. Li Q, Zhang C, Chen R, Xiong H, Qiu F, Liu S, Zhang M, Wang F, Wang Y, Zhou X, Xiao G, Wang X, Jiang Q. Disrupting MALAT1/miR-200c sponge decreases invasion and migration in endometrioid endometrial carcinoma. Cancer Lett. 2016;383:28-40. https://doi.org/10.1016/j.canlet. 2016.09.019.

94. Weidle UH, Birzele F, Kollmorgen G, Ruger R. Long Non-coding RNAs and their Role in Metastasis. Cancer Genomics Proteomics. 2017;14:143-60. https://doi.org/10.21873/cgp.20027.

95. Wu D, Ke Y, Xiao R, Liu J, Li Q, Wang Y. Long non-coding RNA GCInc1 knockdown suppresses progression of epithelial ovarian cancer by recruiting FOXC2 to disrupt the NOTCH1/NF-kappaB/Snail pathway. Exp Cell Res. 2021;399: 112422. https://doi.org/10.1016/j.yexcr.2020.112422.

96. Gordon MA, Babbs B, Cochrane DR, Bitler BG, Richer JK. The long noncoding RNA MALAT1 promotes ovarian cancer progression by regulating RBFOX2-mediated alternative splicing. Mol Carcinog. 2019;58:196205. https://doi.org/10.1002/mc.22919.

97. Sanger JM, Wang J, Gleason LM, Chowrashi P, Dube DK, Mittal B, Zhukareva V, Sanger JW. Arg/Abl-binding protein, a Z-body and Z-band protein, binds sarcomeric, costameric, and signaling molecules. Cytoskeleton (Hoboken). 2010;67:808-23. https://doi.org/10.1002/cm. 20490.

98. Kimura A, Baumann CA, Chiang SH, Saltiel AR. The sorbin homology domain: a motif for the targeting of proteins to lipid rafts. Proc Natl Acad Sci U S A. 2001;98:9098-103. https://doi.org/10.1073/pnas.15125 2898.

99. Zhao L, Wang W, Huang S, Yang Z, Xu L, Yang Q, Zhou X, Wang J, Shen Q, Wang C, Le X, Feng M, Zhou N, Lau WB, Lau B, Yao S, Yi T, Wang X, Zhao $X$, Wei Y, Zhou S. The RNA binding protein SORBS2 suppresses metastatic colonization of ovarian cancer by stabilizing tumor-suppressive immunomodulatory transcripts. Genome Biol. 2018;19:35. https:// doi.org/10.1186/s13059-018-1412-6.
100. Liu T, Yang Y, Xie Z, Luo Q, Yang D, Liu X, Zhao H, Wei Q, Liu Y, Li L, Wang Y, Wang F, Yu J, Xu J, Yu J, Yi P. The RNA binding protein QKI5 suppresses ovarian cancer via downregulating transcriptional coactivator TAZ. Mol Ther Nucleic Acids. 2021;26:388-400. https://doi.org/10.1016/j.omtn. 2021.07.012.

101. Weidensdorfer D, Stohr N, Baude A, Lederer M, Kohn M, Schierhorn A, Buchmeier S, Wahle E, Huttelmaier S. Control of c-myc mRNA stability by IGF2BP1-associated cytoplasmic RNPs. RNA. 2009;15:104-15. https:// doi.org/10.1261/rna.1175909.

102. Knott GJ, Bond CS, Fox AH. The DBHS proteins SFPQ, NONO and PSPC1: a multipurpose molecular scaffold. Nucleic Acids Res. 2016;44:39894004. https://doi.org/10.1093/nar/gkw271.

103. Pellarin I, Dall'Acqua A, Gambelli A, Pellizzari I, D'Andrea S, Sonego M, Lorenzon I, Schiappacassi M, Belletti B, Baldassarre G. Splicing factor proline- and glutamine-rich (SFPQ) protein regulates platinum response in ovarian cancer-modulating SRSF2 activity. Oncogene. 2020;39:4390-403. https://doi.org/10.1038/s41388-020-1292-6.

104. Zhang Y, Gan H, Zhao F, Ma X, Xie X, Huang R, Zhao J. CPEB4-Promoted Paclitaxel Resistance in Ovarian Cancer In Vitro Relies on Translational Regulation of CSAG2. Front Pharmacol. 2020;11: 600994. https://doi. org/10.3389/fphar.2020.600994.

105. Yang X, Potts PR. CSAG2 is a cancer-specific activator of SIRT1. EMBO Rep. 2020;21: e50912. https://doi.org/10.15252/embr.202050912.

106. Yahata H, Kobayashi H, Kamura T, Amada S, Hirakawa T, Kohno K, Kuwano M, Nakano H. Increased nuclear localization of transcription factor YB-1 in acquired cisplatin-resistant ovarian cancer. J Cancer Res Clin Oncol. 2002;128:621-6. https://doi.org/10.1007/s00432-002-0386-6.

107. Danno S, Nishiyama H, Higashitsuji H, Yokoi H, Xue JH, Itoh K, Matsuda T, Fujita J. Increased transcript level of RBM3, a member of the glycinerich RNA-binding protein family, in human cells in response to cold stress. Biochem Biophys Res Commun. 1997;236:804-7. https://doi.org/ 10.1006/bbrc.1997.7059.

108. Prawira A, Munusamy P, Yuan J, Chan CHT, Koh GL, Shuen TWH, Hu J, Yap YS, Tan MH, Ang P, Lee ASG. Assessment of PARP4 as a candidate breast cancer susceptibility gene. Breast Cancer Res Treat. 2019;177:145-53. https://doi.org/10.1007/s10549-019-05286-w.

109. Manoharan R, Seong HA, Ha H. Dual Roles of Serine-Threonine Kinase Receptor-Associated Protein (STRAP) in Redox-Sensitive Signaling Pathways Related to Cancer Development. Oxid Med Cell Longev. 2018;2018:5241524. https://doi.org/10.1155/2018/5241524.

110. Antony F, Deantonio C, Cotella D, Soluri MF, Tarasiuk O, Raspagliesi F, Adorni F, Piazza S, Ciani Y, Santoro C, Macor P, Mezzanzanica D, Sblattero D. High-throughput assessment of the antibody profile in ovarian cancer ascitic fluids. Oncoimmunology. 2019;8: e1614856. https://doi. org/10.1080/2162402X.2019.1614856.

111. Visconte V. Mutations in splicing factor genes in myeloid malignancies: significance and impact on clinical features. Cancers (Basel). 2019. https://doi.org/10.3390/cancers11121844.

112. Millstein J, Budden T, Goode EL, Anglesio MS, Talhouk A, Intermaggio MP, Leong HS, Chen S, Elatre W, Gilks B, Nazeran T, Volchek M, Bentley RC, Wang C, Chiu DS, Kommoss S, Leung SCY, Senz J, Lum A, Chow V, Sudderuddin H, Mackenzie R, George J, Fereday S, Hendley J, Traficante N, Steed H, Koziak JM, Kobel M, McNeish IA, Goranova T, Ennis D, Macintyre G, Silva D, Ramon YCT, Garcia-Donas J, HernandoPolo S, Rodriguez GC, Cushing-Haugen KL, Harris HR, Greene CS, Zelaya RA, Behrens S, Fortner RT, Sinn P, Herpel E, Lester J, Lubinski J, Oszurek O, Toloczko A, Cybulski C, Menkiszak J, Pearce CL, Pike MC, Tseng C, Alsop J, Rhenius V, Song H, Jimenez-Linan M, Piskorz AM, Gentry-Maharaj A, Karpinskyj C, Widschwendter M, Singh N, Kennedy CJ, Sharma R, Harnett PR, Gao B, Johnatty SE, Sayer R, Boros J, Winham SJ, Keeney GL, Kaufmann SH, Larson MC, Luk H, Hernandez BY, Thompson PJ, Wilkens LR, Carney ME, Trabert B, Lissowska J, Brinton L, Sherman ME, Bodelon C, Hinsley S, Lewsley LA, Glasspool R, Banerjee SN, Stronach EA, Haluska P, RayCoquard I, Mahner S, Winterhoff B, Slamon D, Levine DA, Kelemen LE, Benitez J, Chang-Claude J, Gronwald J, Wu AH, Menon U, Goodman MT, Schildkraut JM, Wentzensen N, Brown R, Berchuck A, Chenevix-Trench G, Fazio A, Gayther SA, Garcia MJ, Henderson MJ, Rossing MA, BeeghlyFadiel A, Fasching PA, Orsulic S, Karlan BY, Konecny GE, Huntsman DG, Bowtell DD, Brenton JD, Doherty JA, Pharoah PDP, Ramus SJ. Prognostic gene expression signature for high-grade serous ovarian cancer. Ann Oncol. 2020;31:1240-50. https://doi.org/10.1016/j.annonc.2020.05.019. 
113. Wang K, Li L, Fu L, Yuan Y, Dai H, Zhu T, Zhou Y, Yuan F. Integrated Bioinformatics Analysis the Function of RNA Binding Proteins (RBPs) and their prognostic value in breast cancer. Front Pharmacol. 2019;10:140. https://doi.org/10.3389/fphar.2019.00140.

114. Li W, Gao LN, Song PP, You CG. Development and validation of a RNA binding protein-associated prognostic model for lung adenocarcinoma. Aging. 2020;12:3558-73. https://doi.org/10.18632/aging.102828.

115. Zhao L, Cao J, Hu K, Wang P, Li G, He X, Tong T, Han L. RNA-binding protein RPS3 contributes to hepatocarcinogenesis by post-transcriptionally up-regulating SIRT1. Nucleic Acids Res. 2019;47:2011-28. https://doi. org/10.1093/nar/gky1209.

116. Zhang Z, Wang L, Wang $Q$, Zhang M, Wang B, Jiang K, Ye Y, Wang S, Shen Z. Molecular characterization and clinical relevance of RNA Binding Proteins in Colorectal Cancer. Front Genet. 2020;1 1: 580149. https:// doi.org/10.3389/fgene.2020.580149

117. Fan L, Lin Y, Lei H, Shu G, He L, Yan Z, Rihan H, Yin G. A newly defined risk signature, consisting of three $\mathrm{m}(6) \mathrm{A}$ RNA methylation regulators, predicts the prognosis of ovarian cancer. Aging. 2020;12:18453-75. https://doi.org/10.18632/aging.103811.

118. Lucchesi CA, Zhang J, Ma B, Chen M, Chen X. Disruption of the Rbm38elF4E Complex with a Synthetic Peptide Pep8 Increases p53 Expression. Cancer Res. 2019;79:807-18. https://doi.org/10.1158/0008-5472. CAN-18-2209.

119. Ko SY, Guo H, Barengo N, Naora H. Inhibition of ovarian cancer growth by a tumor-targeting peptide that binds eukaryotic translation initiation factor 4E. Clin Cancer Res. 2009;15:4336-47. https://doi.org/10. 1158/1078-0432.CCR-08-2924.

120. Chen H, Liu J, Wang H, Cheng Q, Zhou C, Chen X, Ye F. Inhibition of RNA-binding protein musashi-1 suppresses malignant properties and reverses paclitaxel resistance in ovarian carcinoma. J Cancer. 2019;10:1580-92. https://doi.org/10.7150/jca.27352.

121. Fu C, Yuan M, Sun J, Liu G, Zhao X, Chang W, Ma Z. RNA-Binding Motif Protein 11 (RBM11) serves as a prognostic biomarker and promotes ovarian cancer progression. Dis Markers. 2021;2021:3037337. https:// doi.org/10.1155/2021/3037337.

122. Wang S, Li Z, Zhu G, Hong L, Hu C, Wang K, Cui K, Hao C. RNA-binding protein IGF2BP2 enhances circ_0000745 abundancy and promotes aggressiveness and stemness of ovarian cancer cells via the microRNA3187-3p/ERBB4/PI3K/AKT axis. J Ovarian Res. 2021;14:154. https://doi. org/10.1186/s13048-021-00917-7.

123. Zhao H, Gao Y, Chen Q, Li J, Ren M, Zhao X, Yue W. RAD51AP1 promotes progression of ovarian cancer via TGF-beta/Smad signalling pathway. J Cell Mol Med. 2021;25:1927-38. https://doi.org/10.1111/jcmm.15877.

124. Wang L, Rowe RG, Jaimes A, Yu C, Nam Y, Pearson DS, Zhang J, Xie X, Marion W, Heffron GJ, Daley GQ, Sliz P. Small-molecule inhibitors disrupt let-7 oligouridylation and release the selective blockade of let-7 processing by LIN28. Cell Rep. 2018;23:3091-101. https://doi.org/10.1016/j. celrep.2018.04.116.

125. Hiramatsu K, Yoshino K, Serada S, Yoshihara K, Hori Y, Fujimoto M, Matsuzaki S, Egawa-Takata T, Kobayashi E, Ueda Y, Morii E, Enomoto T, Naka T, Kimura T. Similar protein expression profiles of ovarian and endometrial high-grade serous carcinomas. Br J Cancer. 2016;114:55461. https://doi.org/10.1038/bjc.2016.27.

126. Hao L, Wang JM, Liu BQ, Yan J, Li C, Jiang JY, Zhao FY, Qiao HY, Wang HQ. m6A-YTHDF1-mediated TRIM29 upregulation facilitates the stem cell-like phenotype of cisplatin-resistant ovarian cancer cells. Biochim Biophys Acta Mol Cell Res. 2021;1868: 118878. https://doi.org/10.1016/j. bbamcr.2020.118878.

\section{Publisher's Note}

Springer Nature remains neutral with regard to jurisdictional claims in published maps and institutional affiliations.

Ready to submit your research? Choose BMC and benefit from:

- fast, convenient online submission

- thorough peer review by experienced researchers in your field

- rapid publication on acceptance

- support for research data, including large and complex data types

- gold Open Access which fosters wider collaboration and increased citations

- maximum visibility for your research: over $100 \mathrm{M}$ website views per year

At BMC, research is always in progress.

Learn more biomedcentral.com/submissions 